\title{
FELICIDADE CLANDESTINA OU A SIGNIFICAÇÃO MARGINAL DA PALAVRA
}

Cláudio Fonseca (CUA)

Resumo: O presente artigo busca discutir em que medida a significação da palavra, do discurso, resulta de uma compreensão ativa e responsiva (BAKHTIN, 1992) inscrita no interior da interação verbal entre sujeitos historicamente constituídos. De acordo com essa perspectiva, os temas ou as isotopias que se constroem no processo comunicativo dependem de se (re)conhecer que a significação se produz com base em uma compreensão global, da totalidade do texto-discurso em oposição a um viés que assenta a significação fora do escopo da interação e da enunciação completa, privilegiando a análise da palavra, sua significação, dentro do sistema linguístico formal e abstrato. Procura-se demonstrar a pertinência da compreensão temática por meio da análise do texto "Felicidade clandestina" de Clarice Lispector (1998), postulando-se que sua significação se constrói com base na tensão entre isotopias (CHARAUDEAU; MAINGUENEAU, 2004).

Palavras-chave: Significação; Compreensão; Tema; Texto; Discurso.

Abstract: The present article seeks to discuss to what extent the meaning of the word, the speech, the result of an active and responsive understanding (BAKHTIN, 1992) entered inside the verbal interaction between subject historically constituted. According to this perspective, the themes or the isotopies that are built in the communicative process depend on if (re)know that meaning is produced on the basis of a global understanding of the whole textspeech as opposed to a bias underpinning the significance outside the scope of interaction and of enunciation. The analysis of the full word, its meaning within the formal and abstract linguistic system. Seeks to demonstrate the relevance of the thematic understanding through the analysis of the text "clandestine Happiness" by Clarice Lispector (1998), positing that its meaning is built based on the tension between isotopies (CHARAUDEAU; MAINGUENEAU, 2004).

Keywords: Meaning; Comprehension; Theme; Text; Speech. 


\section{PRELIMINARES}

A investigação da significação de um ou outro elemento linguístico pode (...) orientar-se para duas direções: para o estágio superior, o tema; neste caso tratar-se-ia da investigação da significação contextual de uma dada palavra nas condições de uma enunciação concreta. Ou então ela pode tender para o estágio inferior, o da significação: neste caso será a investigação da significação da palavra no sistema da língua, ou em outros termos a investigação da palavra dicionarizada. (BAKHTIN, 1992, p.131)

Nas situações de comunicação concreta entre as pessoas, das mais corriqueiras às mais elaboradas, uma das intenções que os sujeitos têm é se fazerem entender, serem compreendidos ainda quando produzem o non sense. Diante disso, se poderia perguntar: que conhecimentos são mobilizados nas atividades linguageiras para que se produza a significação? Como se processa a compreensão? Por que um enunciado faz sentido em um dado contexto interacional?

Essas e outras questões têm ocupado as reflexões de gramáticos, filósofos, linguistas, que ao longo do tempo ofereceram respostas diferentes ao problema da significação.

No âmbito dos estudos semânticos e linguísticos, o problema da significação tem sido abordado ou como um 
fenômeno circunscrito à lógica interna do sistema formal de uma língua, da sua imanência e, nesse caso, ligado à tradição estruturalista, ou como um fenômeno relacionado à natureza enunciativo-discursiva da linguagem, dos sujeitos e do contexto que a atualizam, configurando-se, pois, o estudo da significação em duas direções, tal como observa Bakhtin, na epígrafe inicial.

Neste trabalho, nos limitaremos a tratar a significação vinculada ao problema da compreensão ativa e responsiva e, portanto, integrada à enunciação completa (BAKHTIN, 1992), do seu processamento pelo leitor ou ouvinte, que diante de um texto escrito ou falado, em um dado contexto de interação, mobiliza uma série de conhecimentos linguísticos, textuais, semânticos e discursivos, que lhe permitem apreender o(s) tema(s) ou isotopia(s) de um texto-discurso, em especial o literário, em relação com outros discursos com os quais dialoga.

\section{UM CAMINHO PARA A COMPREENSÃO}

O problema da significação historicamente tem sido objeto de investigação e debate de diversas áreas do conhecimento, entre as quais a filosofia da linguagem e a linguística, esta última, principalmente no âmbito dos estudos semânticos e do discurso. 
Coube a Benveniste (1989), interessado pelas questões relacionadas ao significado, operar o resgate da referência por meio da articulação entre a teoria da enunciação e a teoria dos atos de fala.

Em A forma e o sentido da linguagem, Benveniste (1989) distingue as dimensões semântica e semiótica da linguagem. Para o autor, que se dirige nesse texto a uma plateia de estudiosos da filosofia da linguagem, esta se refere ao sistema das formas da língua, cujos significados se definem enquanto valor que estas formas entretêm uma em relação às outras. Ao se apropriar da língua, em uma situação concreta de comunicação, o falante realiza a dimensão semântica da linguagem, ao colocar a língua em funcionamento, em que o dizer significa agir em relação ao seu interlocutor. É neste terreno que a língua produz sentido para Benveniste, ou seja, é em um dado contexto enunciativo, em que a língua - sistema de formas - se converte em discurso, que a língua de fato significa.

Na verdade, como dissemos acima, as reflexões de Benveniste sobre a significação resultam do diálogo que travou com a filosofia analítica da linguagem, bem como de seus estudos sobre o que denominou de aparelho formal da enunciação. É significativo que um estruturalista, herdeiro 
dos programas de investigação saussuriano, do círculo de Praga e Hjelmsleviano, tenha procedido a um deslocamento nos estudos da linguagem, a fim de redefinir a significação no âmbito do discurso e da enunciação individual.

No entanto, este deslocamento já havia sido realizado por Bakhtin na segunda década do século $X X$ com mais amplitude, na medida em que o linguista russo concebe a enunciação dentro do escopo da interação verbal, determinada pelo contexto imediato e pelo horizonte histórico-social mais amplo.

Em A interação verbal, Bakhtin (1992, p.124) propõe uma ordem metodológica para a compreensão ativa e responsiva da língua, tendo em vista a sua manifestação concreta:

1. análise das formas e tipos de interação relacionados às condições em que se realiza;

2. análise das formas das diferentes enunciações, dos atos de fala correspondentes, relacionados a interação verbal e aos vínculos ideológicos daí decorrentes;

3. análise linguística das formas da língua em ligação com a enunciação e com as formas e tipos de interação.

Como se observa, a proposta de compreensão da língua de Bakhtin concebe o discurso como um todo, uma vez que considera para a análise tanto os aspectos linguísticos, 
semânticos, discursivos como os extradiscursivos, tal como a interação e o contexto imediato e mais amplo a que se vincula.

Nesse sentido, a proposta de entender aqui a significação se insere numa perspectiva sócio-histórico-interacionista, na qual o discurso significa em função da relação com outros discursos com os quais concorda ou polemiza.

\section{O METADISCURSO COMO TEMA MARGINAL EM A FELICIDADE CLANDESTINA}

O conto que dá título ao livro do gênero de Lispector (1998) remete ao período em que a autora viveu a infância na cidade de Recife. Ainda que este dado conduza o leitor a uma leitura autobiográfica do texto, esta informação não resolve em princípio o trabalho de compreensão nem condiciona as possíveis leituras em função da autonomia que o texto ficcional adquire em face à autoria. Aliás, as referências da vida pregressa da autora, antes de se constituírem signos relevantes para a compreensão do texto em questão, podem, ao contrário, desorientar o processamento da significação pelo leitor, pois são dados que invariavelmente são tomados como pistas para a compreensão e caracterização da obra da autora, em detrimento dos aspectos singulares do texto que podem de fato orientar uma trajetória de leitura e revelar traços do estilo que escapam a interpretações 
generalizadoras e consensuais sobre a estética de Lispector. Uma apreensão erótica dos signos do texto nesse caso, reduzida às referências de vida da autora.

A narração se funda na primeira pessoa do discurso, criando de início um efeito de uma narrativa pessoal, quase infantil e confessional, sobre a relação conflituosa entre a narradorapersonagem e sua antagonista, personagem-menina como ela. Não se trata apenas de uma história em que o(s) conflito(s) se resolve $(\mathrm{m})$ com a conquista de um objeto de desejo, o livro As reinações de Narizinho, de Monteiro Lobato, pela narradorapersonagem, pertencente à antagonista.

Felicidade clandestina constitui um sintagma nominal, cuja combinação atribui um valor particular a felicidade, construindo uma quase assertiva, articulada pela cópula oculta: A felicidade é clandestina, cuja predicação questiona um possível conceito, canônico, convencionalizado, universal de felicidade, ao afirmar através do ato de fala algo que se contrapõe, nega a significação habitual de felicidade, presente em outros discursos historicamente construídos com os quais a narradora polemiza: "A felicidade ia ser sempre clandestina para mim" (1998).

Nesse sentido, compreender o que é, o que significa felicidade clandestina pressupõe opor a uma felicidade não 
clandestina, sem atributo algum, cujo significado é estável e universal. Assim, o sintagma nominal que dá título ao conto e ao livro é uma espécie de contra-verbete de um dicionário de uma língua que se constrói na dinâmica discursiva, em que o discurso escrito é de certa maneira parte integrante de uma discussão ideológica em grande escala: ele responde a alguma coisa, refuta, confirma, antecipa as respostas e objeções potenciais, procura apoio, etc. (BAKHTIN, 1992, p.123)

Na leitura que estamos propondo, o discurso e a própria construção de Felicidade clandestina remetem a uma significação marginal de felicidade que, de alguma forma, abala a estabilidade dos discursos e dos atributos que felicidade adquiriu no processo de evolução da língua, o que corrobora a ideia de que, em certo sentido, todo discurso aponta para si mesmo, constituindo um metadiscurso. Ao construir uma história sobre a felicidade, a autora postula um sentido que questiona outros sentidos que o leitor possa ter em seu arquivo mental sobre felicidade, construídos historicamente e que orientam a sua compreensão, criando uma tensão entre temas: aqueles que referendam os sentidos consolidados e aqueles que questionam sua estabilidade. Nos termos de Bakhtin (1992, p.136) a significação de uma enunciação não pode ser sempre igual a si mesma, pois “(...) é absorvida pelo 
tema, e dilacerada por suas contradições vivas, para retornar enfim sob a forma de uma significação com uma estabilidade e uma identidade igualmente provisórias".

O questionamento de felicidade permite deslindar outros temas ou isotopias além daquele que remete à relativa estabilidade da significação das formas da língua, em virtude de os textos literários serem naturalmente pluri-isotópicos (CHARAUDEAU; MAINGUENEAU, 2004), em que o sentido global se constrói com base em diferentes temas.

No texto em tela, o conflito entre narradora-personagem e antagonista se constrói, num primeiro momento a partir de duas qualidades que possuem e que parecem ser objeto da disputa entre elas: de um lado, a antagonista possui uma imagem avessa ao padrão estético infantil: "Ela era gorda, baixa, sardenta (...). Tinha um busto enorme (...)", enquanto a protagonista se encaixa no modelo do grupo ao qual pertence “(...) nós que éramos imperdoavelmente bonitinhas, esguias, altinhas, de cabelos livres"; de outro, a antagonista possui o que a narradora-personagem não tem, não pode adquirir, mas deseja: livros, cuja posse, em função do pai da antagonista ser dono de livraria não garante a sua fruição: “(...) os livros que ela não lia". Parece que a posse, seja da feminilidade infantil, seja do mundo livresco conferem 
à narrativa um conflito que se desenvolve por meio de uma série de atos de fala, cujas trocas entre as protagonistas vão construir uma temática, em que a articulação entre diferentes isotopias possibilita a compreensão ativa e responsiva de "Felicidade clandestina".

Searle (1981) ao postular uma teoria dos atos de fala, afirma que falar é realizar atos de linguagem de acordo com certas regras. Dedica especial atenção aos atos ilocucionários, em que o falante age sobre o ouvinte, ao dar uma ordem, fazer um pedido, fazer uma promessa, etc. No texto em análise, a narradora-personagem é vítima de uma série de humilhações, pois “(...) continuava a implorar-lhe emprestados os livros que ela não lia". Ainda que este ato de fala seja narrado pela forma indireta do discurso narrativo, - leitor pode perceber que esta ação desencadeia uma série de outras. De posse de um saber - a antagonista sabe sobre o desejo que a narradora-personagem nutre pelos livros - motivada por uma vingança, não ser como eram as outras meninas, prometeu à narradora-personagem que Ihe emprestaria o livro que tanto queria: As reinações de Narizinho, de Monteiro Lobato.

A força ilocucionária de prometer em uma enunciação subentendida, recuperada pelo contexto: Vou Ihe emprestar 
o livro amanhã, desencadeia na narradora-personagem a esperança de que a potência daquele ato de fato se concretize. O efeito que tal ato tem sobre a protagonista, além da esperança de que de fato o livro lhe seja entregue, é compreender afinal que a outra estava Ihe fazendo sofrer. Ainda que tenha descoberto o jogo elaborado por sua antagonista, submete-se ao sofrimento como fosse condição da própria vida e das relações sociais: "Eu já começara a adivinhar que ela me escolhera para eu sofrer, às vezes adivinho. Mas adivinhando mesmo, às vezes aceito: como se quem quer me fazer sofrer esteja precisando danadamente que eu sofra". Este saber sobre a vida, a conquista do amor pelo mundo, figurativizado pelo livro que a narradorapersonagem tanto deseja e cuja condição de conquista é o sofrimento, vai acompanhá-la por toda vida: “(...) os dias seguintes seriam mais tarde a minha vida inteira (...)".

A aprendizagem sobre a vida, inclusive sobre o jogo da linguagem marcado pelo conflito nas relações interpessoais faz com que a narradora-personagem sentencie: A Felicidade sempre ia ser clandestina para mim. $O$ aspecto permansivo da expressão verbal reforçada pelo advérbio corrobora a ideia de que a narradora-personagem aprendeu algo sobre a vida: transformou-se de menina em mulher. Percebera no 
processo de conquista do livro, objeto do desejo, possibilitado pela intervenção da mãe da antagonista que desmascarou o jogo elocucional urdido pela filha, que as coisas e as pessoas são transitórias na vida das pessoas, no sentido de não pertencerem a ninguém, ainda que acreditem que possuam coisas e pessoas: "Não era mais uma menina com um livro: era uma mulher com o seu amante".

A descoberta do amor é permeada pela referência transgressora às convenções sociais: ser mulher é possuir um amante em oposição a ter um marido. Observe-se que os sintagmas preposicionais relatados pela preposição com, cujo sentido é em companhia de, marca uma mudança: passa da companhia de um livro que não era seu, pois emprestado, para a de um amante que lhe pertence, ainda que transitoriamente, pois a mãe ordenara: "E você fica com o livro por quanto tempo quiser".

Assim, o querer na sua temporalidade transitória é que deve governar as relações amorosas, diferentemente do que é estabelecido socialmente. Por isso, a felicidade da protagonista se define como clandestina, uma vez que tensiona com o discurso tradicional que legitima as relações amorosas como perenes e independentes da permanência do desejo ou da continuidade do querer. 
Há no conto, pois, um jogo temático em que ser, ter e querer se articulam para construir uma significação de um discurso sobre a felicidade que tensiona com um discurso legitimado historicamente sobre este sentimento. Tal tensão marca tanto o contexto de produção como o de recepção do texto, em virtude desta discussão ideológica ainda permear na prática as relações amorosas, por exemplo, em que elas podem ser permanentes ou transitórias, segundo os valores legitimados ou não socialmente.

\section{CONSIDERAÇÕES FINAIS}

Como foi demonstrado, a compreensão ativa e responsiva, na leitura que realizamos, permeou-se por uma visão global do texto literário, em que os elementos significativos das várias enunciações constituem a sua tessitura e estrutura, possibilitando ao leitor integrá-las à interação de que participa na relação com o autor, fazendo emergir os temas, cuja significação resulta da tensão entre os sujeitos historicamente constituídos ou como Bakhtin (1992, p.132) propugna:

Compreender é opor à palavra do locutor uma contra palavra. (...) $\mathrm{Na}$ verdade, a significação pertence a uma palavra enquanto traço de união entre os interlocutores, isto é, ela só se realiza no processo de compreensão ativa e responsiva. (...) Ela é o efeito da interação do locutor e do receptor produzido 
através do material de um determinado complexo sonoro. É como uma faísca elétrica que só se produz quando há contato dos dois polos opostos. Aqueles que ignoram o tema (que só é acessível a um ato de compreensão ativa e responsiva) e que, procurando definir o sentido de uma palavra, atingem o seu valor inferior, sempre estável e idêntico a si mesmo, é como se quisessem acender uma lâmpada depois de terem cortado a corrente. Só a corrente da comunicação verbal fornece à palavra a luz da sua significação.

\section{REFERÊNCIAS}

BAKHTIN, Mikhail; VOLOSHINOV, Valentin (1992). Marxismo e filosofia da linguagem. São Paulo: Hucitec.

BENVENISTE, Émile (1989). "A forma e o sentido da linguagem". In: Problemas de linguística geral. Campinas-SP: Pontes.

CHARAUDEAU, Patrick; MAINGUENEAU, Dominique (2004). Dicionário de análise do discurso. São Paulo: Contexto.

LISPECTOR, Clarice (1998). "Felicidade clandestina". In: Felicidade clandestina. Rio de Janeiro: Rocco.

SEARLE, John Rogers (1981). Os atos de fala. Coimbra: Almedina.

Claudio Luiz Abreu Fonseca possui graduação em Curso de Letras pela Universidade Estadual Paulista Júlio de Mesquita Filho (1987), Mestrado em Letras e Linguística pela Universidade Federal de Goiás e Doutorado em Letras, Língua Portuguesa, pela Universidade Estadual do Rio de Janeiro. Atualmente é Professor Adjunto do Curso de Licenciatura em Letras do Instituto de Ciências Humanas e Sociais - ICHS, do Câmpus Universitário do Araguaia - CUA, da Universidade Federal de Mato Grosso - UFMT. Tem experiência na área de Linguística, com ênfase em Análise Semiótico-Discursiva, Linguística Aplicada ao 
ensino de língua portuguesa, atuando principalmente nos seguintes temas: ensino de Língua Portuguesa: história, políticas, sentido social, pesquisa e metodologia; formação do professor de língua portuguesa; historiografia linguística e semiótica das culturas.

Recebido em 20 de junho de 2016. Aprovado em 01 de agosto de 2016. 